\title{
Presence of Gasterophilus (Leach, 1817) (Diptera: Oestridae) in horses in Rio Grande do Sul State, Brazil
}

\author{
SAMUEL RODRIGUES FELIX*, CARLOS EUGÊNIO SILVA**, EDUARDO SCHMIDTT*, \\ LEANDRO QUINTANA NIZOLI*, MARCELO MENDES GÖTZE* and SERGIO SILVA DA SILVA*
}

\begin{abstract}
With the purpose of verify the presence of larvae from the genus Gasterophilus in the Rio Grande do Sul State, a study was undertaken using 395 horses taken to slaughter in the city of Pelotas. The material analysis revealed that 126 animals (31,90\%) presented infection, with 100 animals $(25,32 \%)$ infected by Gasterophilus nasalis, and 47 animals (11,90\%) infected by $\mathbf{G}$. intestinalis. These results also represent the first report of the definite establishment of $\mathbf{G}$. intestinalis as a horse parasite in Brazil. The probable implications of G. intestinalis occurrence in Brazil are discussed.
\end{abstract}

Key words: Gasterophilus; G. nasalis; G. intestinalis.

\section{INTRODUCTION}

The genus Gasterophilus (Diptera, Oestridae) includes eight species of flies whose larvae cause gastrointestinal myiasis in equids ${ }^{1}$. In Brazil Gasterophilus intestinalis De Geer, $1776^{2}$ and Gasterophilus nasalis Linnaeus $1758^{3}$ were the two species described until now.

The myiasis develops for a period of 10 to 12 months in different regions of the equine digestive tract ${ }^{4}$. G. nasalis larvae of second and third instar (L2 and L3) are found in the pylorus and first portion of the duodenum, immediately after the pyloric sphincter ${ }^{5}$, whereas L2 and L3 larvae from G. intestinalis are usually found in the non-glandular portion of the stomach.

Generally, gasterophilosis manifests with dysphagia, gastric and intestinal ulceration, gastric obstruction or volvulus, rectal prolapse, anemia, diarrhea, and other digestive problems ${ }^{6}$.

Apart from the losses caused to equids, there are reports of infections caused by gasterophilids in dogs, pigs, birds ${ }^{7}$ and human beings ${ }^{8}$.

Studies on the occurrence and prevalence of the genus Gasterophilus undertaken in Brazil suggest just the presence of G. Nasalis ${ }^{9-15}$. The occurrence of $G$. intestinalis has been reported, in isolated cases of imported animals ${ }^{2,16}$, and therefore the species is not yet considered as established in Brazil ${ }^{14}$.

The updating of the general occurrence and seasonal occurrence of the genus Gasterophilus in Brazil is important, not only to help the clinical diagnosis and control planning of gasterophilosis, but also from a biological and ecological point of view $^{1}$.

This study reports the occurrence of gasterophilids in horses slaughtered at a slaughterhouse in Rio Grande do Sul State, and

\footnotetext{
* Laboratório de Doenças Parasitárias da Faculdade de Veterinária, UFPel, Pelotas, Brasil.

** Setor de Parasitologia, Departamento de Microbiologia, Instituto de Ciências Básicas da Saúde, UFRGS, Porto Alegre, Brasil.
} 
indicates the establishment of G. intestinalis in Brazil.

\section{MATERIALAND METHODS}

The stomachs of 395 horses were analyzed after slaughter at a commercial slaughterhouse in the city of Pelotas, Rio Grade do Sul. The studied horses were from different regions of the State. The city of origin and the sex of each animal were registered, but no specification was made as to breed or age.

After the evisceration, the animals' stomachs were opened on the greater curvature, from the cardia to the pylorus, together with the first portion of the duodenum; these were examined in search for the larval forms of Gasterophilus spp. When found, the point of fixation (cardia, non-glandular region, glandular region, pilorumduodenum) was registered and the sample was collected and stored individually. These samples were taken immediately to the laboratory, where they were weighed and identified by appropriate keys $^{4}$ (Figure 1).

\section{RESULTS}

The findings on the slaughtered animals are presented in Table 1. A hundred and twenty six $(31,90 \%)$ out of 395 animals were infected by Gasterophilus sp. larvae. Of the overall animals infected, males were more parasitised than females, both in relation to the total of males $(34,57 \%)$ as well as the total of positive animals $(66,66 \%)$.

The infection by species and region (mesoregion, Figure 2) of the Rio Grande do Sul State is presented in Table 2. Findings showed $100(77,34 \%)$ horses infected by G. nasalis and $47(48,44 \%)$ horses infected by $G$. intestinalis. Of the animals presenting the disease, 107 $(83,59 \%)$ were suffering the infection of only one species, and $21(16,41 \%)$ presented larvae of both species.

A total of 1.451 larvae of second and third instars was collected, with a mean of 10,97 larvae per animal. Of the total larvae found, 760 $(52,38 \%)$ were of $G$. nasalis and $691(47,62 \%)$, of $G$. intestinalis.

Horses infected by gasterophilids were found in all the mesoregions of the State of Rio Grade do Sul (Table 3). The infection of horses by $G$. nasalis was identified in 24 municipalities, and the infection by $G$. intestinalis was found in 19 municipalities.

The necropsy of the animals revealed that

Table 1. Number and percentage of horses with gasterophilosis according to sex

\begin{tabular}{lrrrrr}
\hline Horses & PG $^{\mathbf{1}}$ & $\mathbf{( \% )}$ & $\mathbf{N G}^{\mathbf{2}}$ & $\mathbf{( \% )}$ & Total \\
\hline Male & 84 & 34.57 & 159 & 65.43 & 243 \\
Female & 42 & 27.63 & 110 & 72.37 & 152 \\
Total & 126 & 31.90 & 269 & 68.10 & 395 \\
\hline
\end{tabular}

1- PG: Positive for gasterophilosis; 2- NG: Negative for gasterophilosis.

Table 2. Regional distribution of the number and percentage of gasterophilids found in horse slaughtered in Rio Grande do Sul

\begin{tabular}{lrrrrrrrr}
\hline Region & $\boldsymbol{G n}^{\mathbf{2}}$ & $\mathbf{( \% )}$ & $\mathbf{G i}^{\mathbf{3}}$ & $\mathbf{( \% )}$ & $\mathbf{1} \mathbf{s p}^{\mathbf{4}}$ & $\mathbf{( \% )}$ & $\mathbf{2} \mathbf{s p .}$ & $\mathbf{( \% )}$ \\
\hline Northeast & 3 & 15.79 & 0 & 0.00 & 3 & 15.79 & 0 & 0.00 \\
Metropolitan $^{\text {Central }}$ & 7 & 24.14 & 4 & 13.79 & 9 & 31.03 & 1 & 3.45 \\
Southeast & 12 & 27.27 & 2 & 4.55 & 12 & 27.27 & 1 & 2.27 \\
Southwest & 40 & 28.78 & 17 & 12.23 & 43 & 30.94 & 7 & 5.04 \\
Northwest & 29 & 22.48 & 19 & 14.73 & 26 & 20.16 & 11 & 8.53 \\
Total & 9 & 25.71 & 5 & 14.29 & 12 & 34.29 & 1 & 2.86 \\
& 100 & 25.32 & 47 & 11.90 & 105 & 26.58 & 21 & 5.32 \\
\hline
\end{tabular}

1- Mid Occidental \& Mid Oriental; 2- Gn: Gasterophilus nasalis; 3- Gi: Gasterophilus intestinalis; 4- sp.: species. 
Table 3. Regional distribution of the number and percentage of gasterophilosis positive horses from a slaughterhouse in Rio Grande do Sul

\begin{tabular}{lrrrrl}
\hline Region & Horses & PG $^{\mathbf{2}}$ & (\%) & NG $^{\mathbf{3}}$ & (\%) \\
\hline Northeast & 19 & 3 & 15.79 & 16 & 84.21 \\
Metropolitan $_{\text {Central }}{ }^{1}$ & 29 & 10 & 34.48 & 19 & 65.52 \\
Southeast & 44 & 13 & 29.55 & 31 & 70.45 \\
Southwest & 139 & 50 & 35.97 & 89 & 64.03 \\
Northwest & 129 & 37 & 28.68 & 92 & 71.32 \\
Total & 35 & 13 & 37.14 & 22 & 62.86 \\
\hline
\end{tabular}

1- Mid Occidental \& Mid Oriental; 2- PG: Positive for gasterophilosis; 3- NG: Negative for gasterophilosis.

most were infected with up to 20 larvae (table 4). Of the 100 animals infected by G. nasalis, 1 presented larvae in the stomach, and from the 47 presenting G. intestinalis, none presented larvae in the duodenum. In all the other animals the two species of gasterophilids were found on their usual anatomic fixation sites.

\section{DISCUSSION}

The results of this study show that, G. nasalis is not the only species of the Gasterophilus genus acclimatised in Brazil. Differing from former studies ${ }^{9,10,13-15}$ this work shows that $G$. intestinalis has definitely established in Brazil. This was confirmed by the presence of the parasite in different municipalities of the whole state, and in Rio Grande do Sul born horses.

The great prevalence of the infection by $G$. nasalis both in relation to the $G$. intestinalis, as well as the number of infected animals and the

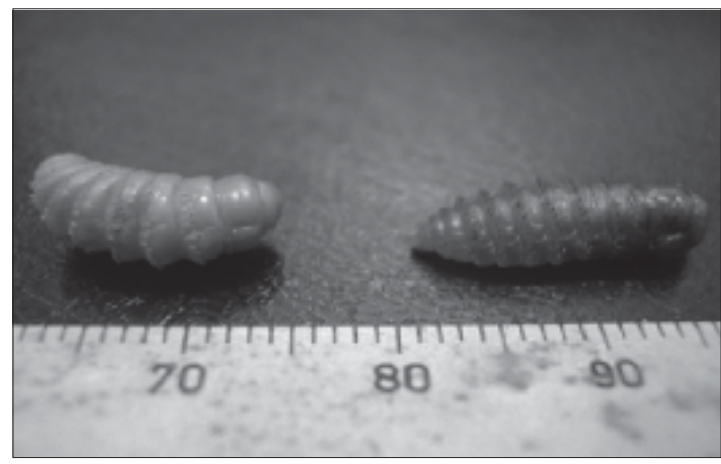

Figure 1.Gasterophilus nasalis (left) and Gasterophilus intestinalis (right) recovered from horses in Rio Grande do Sul.
Table 4. Number and percentage of gasterophilids found per horse

\begin{tabular}{lrr}
\hline $\begin{array}{l}\text { Gasterophilids/ } \\
\text { Infestation }\end{array}$ & n & Horses \\
& 102 & 80.95 \\
\hline From 1 to 20 & 17 & 13.49 \\
From 20 to 50 & 6 & 4.76 \\
From 50 to 100 & 1 & 0.79 \\
$>$ than 100 & 126 & 100.00 \\
Total & & \\
\hline
\end{tabular}

number of collected larvae, can indicate a process of adaptation of the later species. In Italy it was found a predominance of $G$. intestinalis $(95,2 \%)$ over G. nasalis $(44,8 \%)^{1}$. These results were similar to the ones previously found in the State of Victoria, southeast Australia ${ }^{17}$, where the infections were $81 \%$ by $G$. intestinalis and $29 \%$

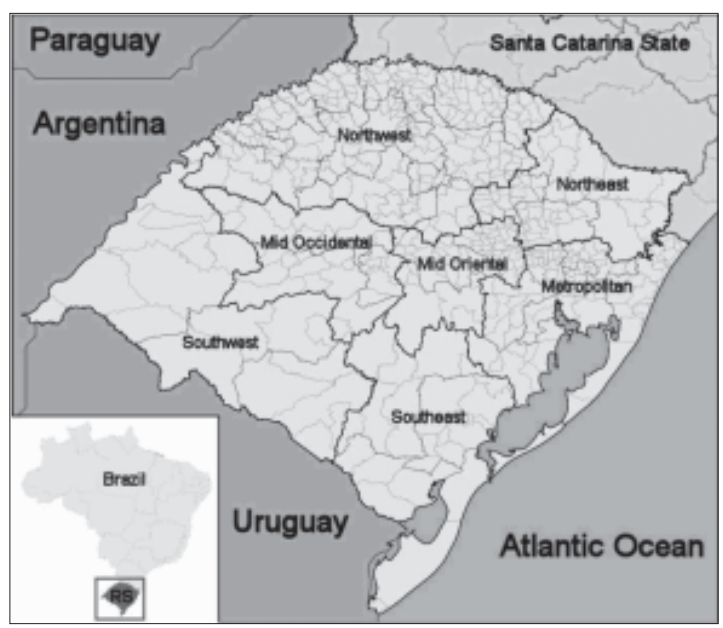

Figure 2. Mesoregions of the Rio Grande do Sul State, Brazil. 
by $G$. nasalis. The predominance of $G$. intestinalis, can be related to the preference of this parasite for the stomach, favouring its access to food, and increasing its biotic potential ${ }^{1}$.

Gasterophilus intestinalis has a worldwide distribution, with a greater number of reports in temperate regions of central Europe, and southsoutheast United States, and increasing in periods of lower temperatures in Europe ${ }^{1}$, Australia ${ }^{17}$ and Jordan $^{18}$.

The climatic situation of the State of Victoria, in Australia, is similar to that of Rio Grande do Sul, with humid winters and temperatures lower than the national average, period of increased $G$. intestinalis occurrence ${ }^{17}$. In Chile the first evidences of $G$. intestinalis was registered in the VIII region (Biobio) ${ }^{19}$, by the identification of eggs of this parasite in the hairs around the horses' mouth, and that the occurrence of this species is grater in winter. Thus, considering the biological and geographic aspects commented above, G. intestinalis has potential to become the most prevalent species of the genus in Rio Grande do Sul, and move on to the other states, especially those that have an annual mean temperature lower than Brazilian's one.

Apart from the difference in the prevalence of both species, the parasitism by $G$. intestinalis is worrisome from the clinical point of view, as there are many reports of severe digestive complications caused by this parasite ${ }^{20-22}$.

Further studies are being conducted to describe the ecology of these parasites, and monitor their occurrence in other Brazilian states or South American countries. However, the authors suggest that immediate preventive measures be taken to control the advance of the introduced species in Brazil.

\section{RESUMO}

Com o objetivo de verificar a presença de larvas do gênero Gasterophilus no Estado do Rio Grande do Sul, foi realizado um estudo com 395 eqüinos sacrificados em um abatedouro da cidade de Pelotas. O material analisado revelou que 126 animais $(31,90 \%)$ apresentaram a infecção, sendo que 100 animais $(25,32 \%)$ estavam infectados por Gasterophilus nasalis e $47(11,90 \%)$ por $G$. intestinalis. Estes resultados também representam o primeiro relato definitivo de estabelecimento de G. intestinalis como parasito de eqüinos no
Brasil. As implicações prováveis da presença de G. intestinalis no Brasil são discutidas.

\section{REFERENCES}

1.- OTRANTO D, MILILLO P, CAPELLI G, COLWELL DD. Species composition of Gasterophilus spp. (Diptera, Oestridae) causing equine gastric myiasis in southern Italy: Parasite biodiversity and risks for extinction. Vet Parasitol 2005; 133: 111-8.

2.- LUTZ A. Contribuição ao estudo dos Oestrídeos brazileiros. Mem. Inst Oswaldo Cruz 1917; 9: 94-112.

3.- IHERING R V. Os Oestrídeos importados, seu papel como parasitas e em particular os Gasterophilus no Brasil. Secretaria da Agricultura, Indústria e Comércio do Estado de São Paulo 1930, 23 p.

4.- ZUMPT F. Myasis in Man and Animals in the Old World. Butterworths, London, 1965.

5.- COGLEY $\mathrm{T}$ P, COGLEY M C. Inter-relationship between Gasterophilus larvae and the horse's gastric and duodenal wall with special reference to penetration. Vet Parasitol 1999; 86: 127-42.

6.- SOULSBY E J L. Helminths, arthropods and protozoa of domesticated animals, 7 th ed. Baillière, Tindall\&Cassell, Eastbourne, United Kingdom, 1982.

7.- HALL M J R, WALL R. Myiasis of humans and domestic animals. Adv Parasitol 1995; 35: 257-334.

8.- ROYCE L A, ROSSIGNOL P A, KUBITZ M L, BURTON FR. Recovery of a second instar Gasterophilus larva in a human infant: a case report. Am J Trop Med Hyg 1999; 60: 403-4.

9.- OLIVEIRA C M, RASSIER D S S, LIGNON G B. Gasterofilose eqüina no Rio Grande do Sul (Brazil). Rev Med Vet S Paulo 1972; 8: 61-6.

10.- LIGNON G B, RASSIER D S S, OLIVEIRA C M. Prevalência dos estágios evolutivos $\mathrm{L}_{2}$ e $\mathrm{L}_{3}$ do Gasterophilus nasalis no Rio Grande do Sul. Arq FacVet UFRGS 1975; 3: 49-56.

11.- CODA M L, WATANABE S, IWANAGA E, et al. Prevalência de Gasterophilus nasalis L. $1761 \mathrm{em}$ eqüídeos abatidos na região norte do Estado do Paraná. Anais do XVIII Congresso Brasileiro de Medicina Veterinária. Camburiú, SC. Resumo 135, p.175, 1982.

12.- MUNDIM M J S, CABRAL D D, TUNALA V. Distribuição geográfica e freqüência de gasterofilose em eqüídeos abatidos em Araguari, minas Gerais. Braz J Vet Res Anim Sci 1992; 29: 211-3.

13.- KLEM M A P, RODRIGUES A C, REZENDE A M L. Gasterofilose em Eqüídeos: Infecção Natural por Gasterophilus nasalis L. (DIPTERA: GASTEROPHILIDAE) no Estado do Rio de Janeiro. Braz J Vet Med 1997; 6: 61-7.

14.- RODRIGUES A C, REZENDE A M L, NOBILING R A,et al. Estudo da Flutuação de Larvas de $3^{\circ}$ ínstar de Gasterophilus nasalis (Linnaeus, 1758) (Diptera: Gasterophilidae) na Microrregião Fluminense do Grande Rio, RJ. Braz J Vet Med 1999; 21: 215-8.

15.- SEQUEIRA J L, TOSTES R A, OLIVEIRA-SEQUEIRA T C. Prevalence and macro- and microscopic lesions produced by Gasterophilus nasalis (Diptera: Oestridae) in the Botucatu Region, SP, Brazil, Vet Parasitol 2001; 102: 261-6. 
16.- GUIMARAES L M, ARAUJO T L, GOMES C E S. Sobre a presença de Gasterophilus intestinalis (De Geer, 1776) em equinos PSC no Estado de São Paulo. Vet Fac Med Vet S Paulo 1954; 5: 189-93.

17.- BUCKNELL D G, GASSER R B, BEVERIDGE J. The prevalence and epidemiology of gastrointestinal parasites of horses in Victoria, Aust. Int J Parasitol 1995; 25: 711-24.

18.- MUKBEL R, TORGERSON PR, ABO-SHEHADA M. Seasonal variations in the abundance of Gasterophilus spp. larvae in donkeys in northern Jordan. Trop Anim Health Prod 2001; 33: 501-9.
19.- SIVERS G, WEBER B. Período de oviposición de Gasterophilus nasalis y G. intestinalis en equinos. VIII Región, Chile. Arch Med Vet 2005; 37: 169-72.

20.- ROONEY J R. Gastric ulceration in foals. Path Vet 1964; 1: 497-503.

21.- DRUDGE J H. Internal Parasites of Horses. American Hoechst Corporation, Somerville, NJ, $17 \mathrm{pp}, 1980$.

22.- DART A J, HUTCHINS D R, BEGG A P. Suppurative splenitis and peritonitis in a horse after gastric ulceration caused by larvae of Gasterophilus intestinalis. Aust Vet J 1987; 64: 155-8.
ANNOUNCEMENT

PARASITOLOGIA LATINOAMERICANA IN INTERNET

Information about Parasitología Latinoamericana and its electronic version can be found in: www.scielo.cl

Correspondencia a:

Carlos Eugênio Silva

Email: ceusilvaster@gmail.com

Depto. Microbiologia, ICBS, Rua Sarmento Leite, 500,

sala 158. CEP: 90050-170; Porto Alegre, RS, Brasil.

Fax: +55 5133083445 . Phone: +55 5133084545

Email: samuelrf@gmail.com 